\title{
President Carter aims to spend 'windfall' oil profits on energy research
}

President Carter last week asked members of the National Academy of Sciences to support his proposal that Congress create an Energy Security Fund, financed by a tax on the "windfall' profits which the oil companies are expected to make following the de-control of oil prices. Such a fund could partly be used to double US investment in energy technology over the next few years.

The President's remarks were made during the course of an address to the annual meeting of the academy, the first to have been delivered to the assembled scientists since President John Kennedy spoke at a NAS meeting one month before his assassination. The Energy Security Fund, he said, which Administration officials estimate could involve collection from the oil companies of up to $\$ 7$ billion a year, would be used not only to provide relief to those least able to pay for more costly energy, but also to finance projects, including both basic and applied research, important to the country's energy future.

"By the second quarter of the 21st century, we will have learned to rely on cleaner, essentially inexhaustible sources of energy. The principal candidates include, of course, fusion and solar technologies as photovoltaics," President Carter said.

"We are preparing right now for these stages of our energy future. Our energy research and development is already larger in its programme size than those of all our allies combined. But we must do more."

The President had particularly harsh words for the oil industry, which is suggesting that the extra money it receives from increased oil prices should be used to finance its own energy development programmes, covering both exploration and research. He accused the companies of trying to 'hoodwink' the American people by passing a windfall profits tax that was in fact designed to provide the companies with loopholes through which they could increase their general revenues.

"They will try to pass this charade off on the American people as a socalled 'plough-back' provision. But it is not a 'plough back'-it is a 'plough under' and 'kick back'. And what is going to be ploughed under is the Energy Security Fund with its aid to research and to the poor," the President said.

"I ask for your support in the battle to pass an honest windfall profits tax .... and I also call on all of you

in the scientific and engineering community to fulfil the trust of the American people by creating the new energy technologies that are so vital to the future of our country."

Although many observers in Washington feel that the President's idea of a windfall profits tax has a greater chance of succeeding in Congress than when it was first suggested last month, some have expressed doubts whether the amount of money that the Federal Government could collect in this way would in fact be as high as the President has suggested.

A report by Ralph Nader's Tax Reform Research Group has said that the proposed tax would pick up "only \$3-4 billion of the new revenues. ie, $20 \%$ rather than $50 \%$ of the increased revenues that the oil companies are expected to receive.

However the chances of Congress accepting the idea have been increased by the large profit increases which the major oil companies have been reporting for the first quarter of 1979. Texaco Inc, for example, reported an $81 \%$ increase in profits over the same period last year, and Gulf Oil Corporation a $61 \%$ increase. A spokesman for the President said that these profit increases greatly strengthened the arguments for a windfall profits tax to be used for research and other purposes.

In his speech to the academy, President Carter also asked the scientists to support his attempts to have the new Strategic Arms Limitation Treaty (SALT II), currently in the closing stages of negotiation with the Soviet Union, ratified by the US Senate.

Of all the fruits of science none is more bitter than nuclear weapons. And of all the responsibilities of nations, none is more urgent than the control of this most terrible menace to our

\section{More US accidents in transporting chemicals}

THERE has been a sharp rise in the numbers of accidents and deaths involving the transportation of hazardous materials such as liquefied natural gas, sodium sulphydrate, anhydrous ammonia and chlorine, according to a report published last week in Washington by the research service of the Library of Congress. According to the report, there were 45 deaths and 1,411 injuries involving the transport of hazardous materials in 1978, compared to 32 deaths and 749 injuries in 1977 and an average of 21 deaths and 592 deaths over the previous

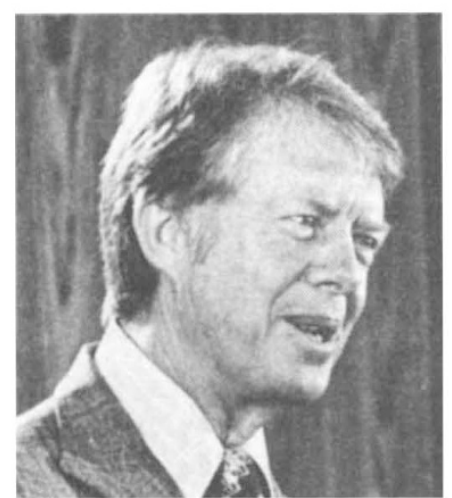

lives and to our civilisation," he said.

Many of the issues involved in assessing the treaty were very complex technically, and the American people would look to the scientific community to help shape an educated public debate. "Many of you devoted much effort to the debate over SALT I, and you played a major role in forming the consensus that developed to support that treaty. Today I ask for a renewal of that commitment."

The President also referred to the increasing costs of major scientific experiments--in contrast to the situation facing scientists such as Albert Einstein who required "little more than a few sharpened pencils and a quiet place to think"-and the choice that this posed between doing experiments on one's own, or in cooperation with other countries.

"We must continue to choose cooperation-for reasons that go beyond the considerable benefits of sharing costs and sharing ideas," the President said. "With our traditional friends, scientific and technological cooperation can strengthen existing bonds. With others, who may not be so friendly, it can help to bridge political, ideological and cultural division." David Dickson period. The high accident rates in 1978 had partly reflected two major incidents, the explosion of a tank-car in Waverly, Tennessee, which killed 15 persons and injured 48 others, and the de-railment of a goods wagon in Youngstown, Florida, which resulted in eight deaths and injured 158. The report says that present federal inspections may not be adequate, citing the fact that the Department of Transportation's Material Transportation Bureau has only six full-time inspectors to cover 20,000 container supply firms and 100,000 shippers. 